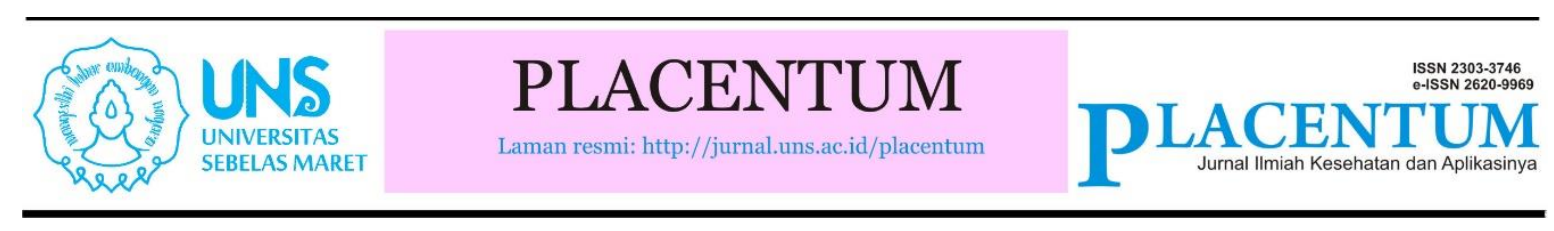

\title{
Overview of The Vaccine Cold Chain System in Five Semarang City Health Centers
}

\author{
Dian Nintyasari Mustika ${ }^{1}$, Sherkia Ichtiarsi Prakasiwi² \\ ${ }^{1}$ Midwifery Program, Faculty of Nursing and Health Sciences, Universitas Muhammadiyah Semarang, Jl. \\ Kedungmundu Raya no 18 Semarang \\ E-mail:dian.nintya@unimus.ac.id
}

\begin{abstract}
Immunization is an effort to reduce morbidity rate, mortality rate, and birth defects in children. It is either a regular or supplemental program for PD3I or vaccine-preventable diseases such as TB, diphtheria, pertussis, tetanus, hepatitis B, polio, and rubella. An infant ideally receives a complete basic vaccine which consists of one dosage of $\mathrm{BCG}$, three dosages of DPT, four dosages of Polio, three dosages of HB, and one dosage of MR. The immunization program is said to be effective and able to decrease the disease when the implementation is well completed and the immunization service quality is guaranteed based on the standard, especially the implementation of vaccine cold chain. The aim of this study is to investigate the condition of vaccine cold chain equipment at five community health centers in Semarang city.

It was an observational descriptive research with a cross-sectional design conducted in five community health centers in Semarang city. The sampling technique used in this research was consecutive sampling. The respondents consisted of 5 vaccine managers at the community health center. The data were collected through a questionnaire which was then analyzed by using univariate analysis. It was found that most of the respondents $(80.0 \%)$ did not provide a cold room in its building. Few respondents (40\%) said that they provided the national standardized (SNI) and WHO's Performance Quality and Safety (PQS) standardized vaccine refrigerator. Meanwhile, only $20 \%$ of the respondents stated that they provided the national standardized (SNI) and PQS standardized vaccine freezer. On the other hand, $60 \%$ of respondents explained that the tape on the thermostat vaccine refrigerator/freezer was already installed. The same result also happened in which $60 \%$ of respondents also explained that they provided Indonesian national standardized (SNI) and PQS standardized disposable or reusable cold packs. Further, $100 \%$ of respondents stated that they provided either vaccine carriers to carry out the vaccine to the immunization service site, cold packs and dry ice in the cold pack, or VVM as the temperature indicator such as thermometer and temperature record chart. It is expected that each health center has a refrigerator/ freezer vaccine according to SNI and PQS from WHO.
\end{abstract}

Keywords: Cold chain, Vaccine

\section{INTRODUCTION}

Immunization is an effort to actively improve someone's immunity toward a particular disease so that when the disease infects this person, there will be no severe symptoms. Some of the infectious diseases 
included in the vaccine-preventable diseases are $\mathrm{TB}$, diphtheria, tetanus, hepatitis $\mathrm{B}$, pertussis, rubella, polio, meningitis, and Pneumonia. Children with proper dosage of vaccine would be protected from those dangerous diseases which could lead to defects or death. ${ }^{[1]}$.

Some points that should be considered in storing vaccines are 1). Temperature Influence: the improper temperature could reduce the potency and efficacy of the vaccine, 2). Sunrays Influence: make sure the vaccine avoids direct sunray, especially for the BCG vaccine, 3). Humidity Influence: The better the packaging, the less humidity influences the vaccine. Airtight bottles and ampoule are the best containers for the vaccine. Here is the proper vaccine storage: Cold Room $\left(2^{\circ} \mathrm{C}\right.$ to $8^{\circ} \mathrm{C}$ temperature for BCG, rubella, DPT, TT, and other vaccines, and $-2^{\circ} \mathrm{C}$ temperature for polio vaccine), regular temperature check, inventory stock, the implementation of First In First Out (FIFO System) dan Expire Date, the use of Batch Delivery Record form as a stock release document, and the stock release based on the delivery request and receiver's warehouse capacity ${ }^{[2]}$.

The unmanaged cold chain system could decrease the quality and effect of each vaccine. A qualified vaccine could boost immunity and prevent vaccine-preventable diseases $^{[2]}$.

The community health center is an immunization service unit with the working area including Posyandu (Maternal and Children Integrated Healthcare Center), Elementary School, and Midwife Clinic. Therefore, the cold chain system implemented in the community health center should meet the standard as it could guarantee the quality of the vaccine. This research describes the implementation of a cold chain system in a community health center based on the module of vaccine cold chain management ${ }^{[3]}$.

\section{RESEARCH METHODOLOGY}

It was an observational descriptive research with a cross-sectional design conducted at five community health centers around Semarang, which were at Puskesmas Kedungmundu, Puskesmas Bangetayu, Puskesmas Tlogosari Kulon, Puskesmas Ngesrep, and Puskesmas Srondol. The inclusion criteria in this study were health workers who had attended vaccine management training. The sampling technique used was consecutive sampling. Questionnaires were made by researchers and data were collected using an instrument in the form of a questionnaire. Data analysis was carried out by univariate analysis.

\section{RESULTS}

\section{Univariate Analysis}

The univariate analysis of the research variables describes the distribution of the variables which includes characteristic variables such as age, education level, and vaccine management training participation.

Table 1. Respondents' Characteristics

\begin{tabular}{llc}
\hline $\begin{array}{l}\text { Respondents' } \\
\text { Characteristic }\end{array}$ & (f) & $\%$ \\
\hline Age & 1 & 20.0 \\
$\leq 35$ years old & 4 & 80.0 \\
$>35$ years old & & \\
& & \\
Education & 3 & 60.0 \\
DIII graduated & 2 & 40.0 \\
DIV graduated & & \\
\hline
\end{tabular}

Primary data, 2021.

Table 1 shows that four of the respondents $(80 \%)$ were less than 35 years old, three respondents $(60 \%)$ were DIII graduates, and only one respondent $(20 \%)$ never had participated in vaccine management training. 
Table 2. Vaccine Storage Equipment

\begin{tabular}{|c|c|c|c|c|c|c|}
\hline \multirow{2}{*}{ Statement } & \multicolumn{2}{|c|}{ Yes } & \multicolumn{2}{|c|}{ No } & \multicolumn{2}{|c|}{ Total } \\
\hline & $\mathrm{N}$ & $\%$ & $\mathrm{n}$ & $\%$ & $\mathrm{n}$ & $\%$ \\
\hline Is a cold room available? & 1 & 20.0 & 4 & 80.0 & 5 & 100.0 \\
\hline Statement & \multicolumn{2}{|c|}{ Yes } & \multicolumn{2}{|c|}{ No } & \multicolumn{2}{|c|}{ Total } \\
\hline & $\mathrm{N}$ & $\%$ & $\mathrm{n}$ & $\%$ & $\mathrm{n}$ & $\%$ \\
\hline $\begin{array}{l}\text { Is a freezer room } \\
\text { available? }\end{array}$ & 0 & 0.0 & 5 & 100.0 & 5 & 100.0 \\
\hline \multirow{2}{*}{ Statement } & \multicolumn{2}{|c|}{ Yes } & \multicolumn{2}{|c|}{ No } & \multicolumn{2}{|c|}{ Total } \\
\hline & $\mathrm{n}$ & $\%$ & $\mathrm{n}$ & $\%$ & $\mathrm{n}$ & $\%$ \\
\hline $\begin{array}{l}\text { Is }-2^{\circ} \mathrm{C} \text { to }-8^{\circ} \mathrm{C} \text { Vaccine } \\
\text { refrigerator based on SNI } \\
\text { and PQS of WHO } \\
\text { available? }\end{array}$ & 2 & 40.0 & 3 & 60.0 & 5 & 100.0 \\
\hline
\end{tabular}

\begin{tabular}{lcccccc}
\hline \multicolumn{1}{c}{ Statement } & \multicolumn{2}{c}{ Top open } & \multicolumn{2}{c}{ Front open } & \multicolumn{2}{c}{ Total } \\
& $\mathrm{n}$ & $\%$ & $\mathrm{n}$ & $\%$ & $\mathrm{n}$ & $\%$ \\
\hline $\begin{array}{l}\text { Which one is the Vaccine } \\
\begin{array}{l}\text { Refrigerator opening } \\
\text { model? }\end{array}\end{array}$ & 4 & 80.0 & 1 & 20.0 & 5 & 100.0 \\
\hline
\end{tabular}

\begin{tabular}{|c|c|c|c|c|c|c|}
\hline \multirow{2}{*}{ Statement } & \multicolumn{2}{|c|}{ System } & \multicolumn{2}{|c|}{ No } & \multicolumn{2}{|c|}{ Total } \\
\hline & $\mathrm{n}$ & $\%$ & $\mathrm{n}$ & $\%$ & $\mathrm{n}$ & $\%$ \\
\hline $\begin{array}{l}\text { How is the compression } \\
\text { and absorption system of } \\
\text { the Vaccine }\end{array}$ & $\begin{array}{c}\text { Compression } \\
2\end{array}$ & 40.0 & 1 & 20.0 & 5 & 100.0 \\
\hline Refrigerator? & $\begin{array}{c}\text { Absorption } \\
2\end{array}$ & 40.0 & & & & \\
\hline \multirow{2}{*}{ Statement } & \multicolumn{2}{|c|}{ Yes } & \multicolumn{2}{|c|}{ No } & \multicolumn{2}{|c|}{ Total } \\
\hline & $\mathrm{n}$ & $\%$ & $\mathrm{n}$ & $\%$ & $\mathrm{n}$ & $\%$ \\
\hline $\begin{array}{l}\text { Is the }-15^{\circ} \mathrm{C} \text { to }-25^{\circ} \mathrm{C} \\
\text { Vaccine refrigerator } \\
\text { based on SNI and PQS of } \\
\text { WHO available? }\end{array}$ & 1 & 20.0 & 4 & 80.0 & 5 & 100.0 \\
\hline \multirow{2}{*}{ Statement } & \multicolumn{2}{|c|}{ Top open } & \multicolumn{2}{|c|}{ No } & \multicolumn{2}{|c|}{ Total } \\
\hline & $\mathrm{n}$ & $\%$ & $\mathrm{n}$ & $\%$ & $\mathrm{~N}$ & $\%$ \\
\hline $\begin{array}{l}\text { Which one is the Vaccine } \\
\text { Refrigerator opening } \\
\text { model? }\end{array}$ & 2 & 40.0 & 3 & 60.0 & 5 & 100.0 \\
\hline \multirow{2}{*}{ Statement } & \multicolumn{2}{|c|}{ System } & \multicolumn{2}{|c|}{ No System } & \multicolumn{2}{|c|}{ Total } \\
\hline & $\mathrm{n}$ & $\%$ & $\mathrm{n}$ & $\%$ & $\mathrm{~N}$ & $\%$ \\
\hline $\begin{array}{l}\text { How is the compression } \\
\text { and absorption system of } \\
\text { the Vaccine } \\
\text { Refrigerator? }\end{array}$ & $\begin{array}{c}\text { Compression } \\
1\end{array}$ & 20.0 & 4 & 80.0 & 5 & 100.0 \\
\hline \multirow{2}{*}{ Statement } & \multicolumn{2}{|c|}{ Yes } & \multicolumn{2}{|c|}{ No } & \multicolumn{2}{|c|}{ Total } \\
\hline & $\mathrm{n}$ & $\%$ & $\mathrm{n}$ & $\%$ & $\mathrm{~N}$ & $\%$ \\
\hline $\begin{array}{l}\text { Is a tape installed on the } \\
\text { thermostat vaccine } \\
\text { refrigerator/freezer? }\end{array}$ & 3 & 60.0 & 2 & 40.0 & 5 & 100.0 \\
\hline
\end{tabular}

Primary data, 2021. 
Based on Table 2, it was found that $80 \%$ of respondents said that there was no cold room, $100 \%$ of respondents stated that there was no freezer room, and $40 \%$ of respondents explained that they provided national standardized and WHO's PQS vaccine refrigerators. Dealing with the vaccine refrigerator opening model, it was found that $80 \%$ of respondents had a top open vaccine refrigerator and $20 \%$ of respondents had a front open vaccine refrigerator. Meanwhile, $40 \%$ of respondents used either an absorption system for the vaccine refrigerator or a vaccine refrigerator with a compression system respectively.
Further, $20 \%$ of respondents stated that there was SNI and WHO's PQS standardized vaccine freezer, while $80 \%$ of respondents stated that there was no standardized vaccine freezer. Dealing with the vaccine freezer model, $40 \%$ of respondents had the top open vaccine freezer, but $60 \%$ of respondents did not have either the top open or front open vaccine freezer. However, $20 \%$ of respondents used a vaccine freezer with a compression system. Furthermore, $60 \%$ of respondents stated that the tape was installed on the vaccine refrigerator/freezer, and $40 \%$ of respondents stated that they did not install the tape.

Table 3. Vaccine Carrier

\begin{tabular}{|c|c|c|c|c|c|c|}
\hline \multirow{2}{*}{ Statement } & \multicolumn{2}{|l|}{$\mathrm{Ya}$} & \multicolumn{2}{|c|}{ No } & \multicolumn{2}{|c|}{ Total } \\
\hline & $\mathrm{N}$ & $\%$ & $\mathrm{n}$ & $\%$ & $\mathrm{~N}$ & $\%$ \\
\hline $\begin{array}{l}\text { Does the reusable or } \\
\text { disposable cool/cold } \\
\text { box meet the SNI } \\
\text { and WHO's PQS } \\
\text { standard? }\end{array}$ & 3 & 60.0 & 2 & 40.0 & 5 & 100.0 \\
\hline \multirow{2}{*}{ Statement } & \multicolumn{2}{|l|}{ Ya } & \multicolumn{2}{|c|}{ No } & \multicolumn{2}{|c|}{ Total } \\
\hline & $\mathrm{N}$ & $\%$ & $\mathrm{n}$ & $\%$ & $\mathrm{~N}$ & $\%$ \\
\hline $\begin{array}{l}\text { Is the vaccine carrier } \\
\text { available to bring the } \\
\text { vaccine to the } \\
\text { immunization } \\
\text { service unit? how } \\
\text { many carriers are } \\
\text { available? }\end{array}$ & $\begin{array}{c}5 \\
\text { Community Health } \\
\text { center : } \\
\text { Bangetayu : } 5 \\
\text { Tlogosari Kulon : } 7 \\
\text { Ngesrep : } 12 \\
\text { Srondol : } 8 \\
\text { Kedungmundu : } 15\end{array}$ & 100.0 & 0 & 0.0 & 5 & 100.0 \\
\hline
\end{tabular}

Primary data, 2021.

Table 3 shows that $60 \%$ of respondents stated that the available cold/cool box met the SNI and WHO's PQS standard, while $40 \%$ of respondents did not provide cold/cool box. Further, $100 \%$ of respondents stated there was a vaccine carrier to bring the vaccine to the immunization service unit. 
Table 4. Temperature Keeper Equipment

\begin{tabular}{|c|c|c|c|c|c|}
\hline \multirow{2}{*}{ Statement } & \multicolumn{2}{|r|}{ Yes } & \multicolumn{2}{|c|}{ No } & Total \\
\hline & $\mathrm{n}$ & $\%$ & $\mathrm{~N}$ & $\%$ & $\mathrm{~N} \%$ \\
\hline $\begin{array}{l}\text { Is liquid } \\
\text { cold/ice } \\
\text { pack } \\
\text { available } \\
\text { near the } \\
\text { evaporator? }\end{array}$ & 5 & 100.0 & 0 & 0.0 & 100.0 \\
\hline \multirow{2}{*}{ Statement } & & Yes & \multicolumn{2}{|c|}{ No } & Total \\
\hline & $\mathrm{n}$ & $\%$ & $\mathrm{~N}$ & $\%$ & $\mathrm{~N} \%$ \\
\hline $\begin{array}{l}\text { Is frozen } \\
\text { cool/cold } \\
\text { pack } \\
\text { available }\end{array}$ & 5 & 100.0 & 0 & 0.0 & $\begin{array}{ll}5 & 100.0\end{array}$ \\
\hline \multirow{2}{*}{ Statement } & \multicolumn{2}{|r|}{ Yes } & \multicolumn{2}{|c|}{ No } & Total \\
\hline & $\mathrm{n}$ & $\%$ & $\mathrm{~N}$ & $\%$ & $\mathrm{~N} \%$ \\
\hline $\begin{array}{l}\text { Is dry ice } \\
\text { available } \\
\text { within the } \\
\text { cool pack? }\end{array}$ & 4 & 80.0 & 1 & 20.0 & $\begin{array}{ll}5 & 100.0\end{array}$ \\
\hline
\end{tabular}

Primary data, 2021.

From table 4, it could be seen that $100 \%$ of respondents stated that there was a liquid cold pack near the evaporator and a frozen cold/ice pack/box. Meanwhile, $80 \%$ of respondents stated there was dry ice in the cool pack, but $20 \%$ of them said there was not any dry ice.

Table 5. Temperature Monitoring Equipment

\begin{tabular}{lcccccc}
\hline \multirow{2}{*}{ Statement } & \multicolumn{2}{c}{ Yes } & \multicolumn{2}{c}{ No } & \multicolumn{2}{c}{ Total } \\
& $\mathrm{N}$ & $\%$ & $\mathrm{~N}$ & $\%$ & $\mathrm{~N}$ & $\%$ \\
\hline Is analog & 5 & 100.0 & 0 & 0.0 & 5 & 100 \\
temperature & & & & & & .0 \\
monitoring & & & & & & \\
equipment & & & & & \\
/thermomet \\
er
\end{tabular}

device available?

Statement Yes No Total

\begin{tabular}{ccccccc} 
& $\mathrm{N}$ & $\%$ & $\mathrm{n}$ & $\%$ & $\mathrm{~N}$ & $\%$ \\
\hline Is a freeze & 4 & 80.0 & 1 & 20. & 5 & 100
\end{tabular}
tag/freeze watch available to monitor the cold temperature exposure on a vaccine?

\begin{tabular}{llrrrrr}
\hline \multirow{2}{*}{ Statement } & \multicolumn{2}{c}{ Yes } & \multicolumn{2}{c}{ No } & \multicolumn{2}{c}{ Total } \\
& $\mathrm{N}$ & $\%$ & $\mathrm{n}$ & $\%$ & $\mathrm{~N}$ & $\%$ \\
\hline Is VVM as & 5 & 100.0 & 0 & 0.0 & 5 & 100 \\
an indicator & & & & & & .0
\end{tabular}
available?

\begin{tabular}{llccccc}
\multicolumn{1}{c}{ Statement } & \multicolumn{2}{c}{ Yes } & \multicolumn{2}{c}{ No } & \multicolumn{2}{c}{ Total } \\
& $\mathrm{N}$ & $\%$ & $\mathrm{n}$ & $\%$ & $\mathrm{~N}$ & $\%$ \\
Is the & 5 & 100.0 & 0 & 0.0 & 5 & 100 \\
temperature & & & & & & .0
\end{tabular}

record chart

available?

Primary data, 2021.

Based on Table 5, 100\% of respondents stated that the analog temperature monitoring equipment /thermometer was available. $80 \%$ of the respondents also stated that a continuous temperature monitoring/recording device was available, while $20 \%$ of them stated that the device was not available. It was also found that $80 \%$ of respondents stated freeze tag/freeze watch was available to monitor the cold temperature exposure on the vaccine, but $20 \%$ of them said there was not any freeze tag. Furthermore, 100\% of respondents stated that there was temperature record graphics.

\section{DISCUSSION}

A vaccine cold chain is a correlated procedure designed to keep the recommended vaccine temperature from the production point to the service point. Vaccine cold chain equipment is all the equipment used to keep the vaccine temperature in check ${ }^{[4]}$. 
From the research, it was found that the community health center provided neither a cold room nor a freezer room with the percentage of $80 \%$ and $100 \%$ of respondents respectively. Cold room and freezer room are used to keep a big amount of vaccine so that it must be available at the regional or provincial level with the big amount of community and is geographically located from the capital city. In this case, Semarang is the capital City of Central java and it is accessible from Central Java Provincial Health Office so a cold room is not necessary.

Two respondents $(40 \%)$ stated that the Indonesian National Standard (SNI) and WHO's PQS standardized vaccine refrigerator was available at their community health center, while three respondents $(60 \%)$ stated that the standardized vaccine refrigerator was not available. Dealing with the vaccine refrigerator model, four respondents $(80 \%)$ stated that they had a top open refrigerator, while only one respondent (20\%) had a front open refrigerator. Furthermore, it was also found that two respondents $(40 \%)$ used a vaccine refrigerator with an absorption system, two respondents $(40 \%)$ used a compression system, and one respondent with no system. A vaccine refrigerator is a space to store vaccines between $2^{\circ}$ to $8^{\circ} \mathrm{C}$, meanwhile, a vaccine freezer is a space to store vaccines between $-15^{\circ} \mathrm{C}$ to $-25^{\circ} \mathrm{C}$. Vaccine refrigerator and freezer must meet the standard from SNI and WHO's PQS. Based on its opening, the vaccine refrigerator/freezer is divided into the top open and front open. Meanwhile, based on its cooling system, the refrigerator is divided into two systems, which are absorption and compression systems. In the top open refrigerator, the temperature is well kept, as when the door is opened, the cold temperature from above would go down and keep in the refrigerator. When the electricity is off, the temperature could last for $6-10$ hours (without door opening). On the other hand, the front open refrigerator is relatively unstable as when the electricity is off, it could only stay for two hours (without door opening). Meanwhile, the vaccine refrigerator with a compression system is known to be able to lower the temperature faster, compared to the refrigerator with an absorption system $^{[4]}$.

Vaccine carrier which is used to carry and keep the vaccine from a place to another place within the recommended temperature must meet the standard from SNI and WHO's PQS. It is aimed to preserve vaccine condition from its initial condition. There are three kinds of vaccine carriers, which are disposable cold/cool box, reusable cold/cool box, and vaccine carrier. Based on the results, it was found that three respondents $(60 \%)$ stated that the disposable and reusable cold/cool box met the SNI and WHO's PQS, while two respondents (40\%) did not have a standardized cold/cool box. It is expected that all the vaccine carriers should meet SNI and WHO's PQS in order for the vaccine quality to be well maintained. Five respondents $(100 \%)$ stated that a vaccine carrier was available to carry the vaccine to the immunization place. The number of vaccine carriers for each community health center is known to be sufficient, as Puskesmas Bangetayu 5, Tlogosari Kulon 7, Ngesrep 12, Srondol 8, and Kedungmundu 15.

A cool pack (liquid) is a square plastic pack filled with water and later being cooled in the vaccine refrigerator at $2^{\circ}$ to $8^{\circ} \mathrm{C}$ for at least 12 hours (near the evaporator) while a cold pack (frozen) is a square plastic pack filled with water and later being frozen in the vaccine refrigerator at $-15^{\circ}$ to $-25^{\circ} \mathrm{C}$ for at least 24 hours. Based on the results, it was found 5 respondents $(100 \%)$ stated that a cool pack (liquid) near the evaporator and a cold pack (frozen) were available in their community health center. There were four respondents $(80 \%)$ who said that dry ice was available in a cool pack, while only one respondent (20\%) stated that dry ice was not available. A cold pack is not recommended, as the use of a cold pack in the immunization program within the small scope may damage the freeze-sensitive vaccines ${ }^{[4]}$. 
There are four kinds of temperature monitoring devices, such as analog temperature monitor, continuous temperature monitor and recorder, cool temperature exposure, and VVM. Based on the results, it was known that five respondents (100\%) explained that an analog temperature monitor/thermometer was available in their community health center. Out of five respondents, four respondents $(80 \%)$ stated that a continuous temperature monitor device was available in their community health center, but it was not available in one of the respondents (20\%). Based on the cold chain management guidelines for immunization administrators, a cool room, refrigerator, cool box, and vaccine carrier should be completed with a thermometer to control the temperature during vaccine transportation from the capital to the community health center, and even to the Posyandu. The administrator must make sure that the cold chain is controlled by a thermometer to maintain vaccine quality.

There were four respondents $(80 \%)$ who stated that a free tag/freeze watch was available in their community health center, while one respondent stated that the freeze tag was not available. A freeze tag is an equipment to monitor the exposure of vaccines to cold temperatures. This is an electrical device with a check (V) or cross (X) sign. When the check sign turns to a cross sign, it means that the vaccines are exposed to under $-0^{\circ} \mathrm{C}$ temperature for more than an hour. The finding of this research is in line with the research conducted by Maksuk from Health Polytechnic of Palembang on 14 community health centers at Palembang in 2011. The research showed that out of 14 community health centers, freeze tags were not available in five vaccine refrigerators $(35.7 \%)$ to maintain the cold chain system.

Furthermore, there were five respondents $(100 \%)$ who also stated that that they provided VVM as an indicator. VVM is the monitor for heat temperature for the immunizations program. VVM is also beneficial to warn the administrator when they should avoid using the vaccine, enable the vaccine used outside the cold chain system, and guide the administrator about which vaccine should be firstly used or distributed. In addition, five respondents $(100 \%)$ stated that temperature record graphic was available in their community health center. ${ }^{[4]}$.

\section{CONCLUSION}

From the results, it is found that the rubella vaccine cold chain administrator in five community health centers of Semarang Health Office is D III qualified, but only one who had participated in the vaccine management training. Most of the facilities and equipment in those five community health centers are sufficient and most of them have met the SNI and WHO's PQS standard.

\section{SUGGESTION}

It is recommended for the health administrator to improve the knowledge and competence by participating in training related to vaccine management. On the other hand, for the next researcher, it is suggested to conduct further research about the evaluation of cold chain system implementation in healthcare centers.

\section{REFERENCES}

1. Pusat Pendidikan dan Pelatihan Tenaga Kerja, 2014, Buku Ajar Imunisasi

2. KPC PEN, 2020, Buku Saku \#Infovaksin

3. Madeppungeng M, 2018, Buku Panduan Prosedur Vaksinasi

4. Kementrian Kesehatan Republik Indonesia, Modul Pengelolaan Rantai Dingin Vaksin

5. Kemenkes RI. 2013. Peraturan Menteri Kesehatan Nomor 42 Tahun 2013 tentang Penyelenggaraan Imunisasi. Kementerian Kesehatan Republik Indonesia. Jakarta. 
6. Dinas Kesehatan Kota Semarang, 2019, Profil Kesehatan Kota Semarang

7. Dinas Kesehatan Provinsi Jawa Tengah, 2019, Profil Kesehatan Jawa Tengah

8. WHO, UNICEF, dan World bank. 2009. State of the World's Vaccines and Immunization Third edition. World Health Organization. Geneva, Switzerland 